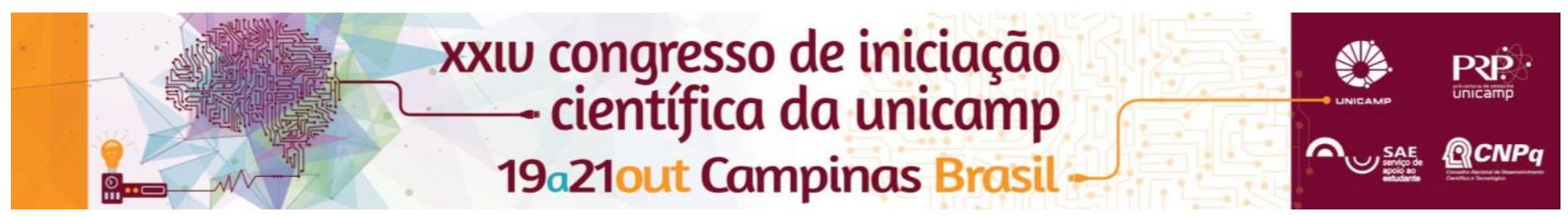

\title{
A passagem da arte moderna para a arte contemporânea pelo prisma de Lygia Clark.
}

\author{
Aluna: Amanda Bueno Villar Inocencio Costa, RA:145180. \\ Orientadora: Profa. Dra. Mariana Miggiolaro Chaguri.
}

\section{Resumo}

Esta pesquisa tem como propósito analisar a trajetória da produção artística de Lygia Clark, investigando as transformações na forma propostas pela artista, relacionando-as com as mudanças no campo artístico moderno brasileiro e com a sociedade. O público de arte é entendido aqui como mediador essencial entre a forma artística e a vida social, sendo elemento chave para problematizar a possível transição entre a arte moderna e a arte contemporânea no Brasil.

\section{Palavras-chave:}

Lygia Clark, Arte Neoconcreta, Arte Contemporânea

\section{Introdução}

Esta pesquisa objetiva investigar as relações entre a produção artística de Lygia Clark e sua intersecção na arte moderna e contemporânea brasileira. Para isso, releva-se o contexto artístico, a circulação no Museu de Arte Moderna do Rio de Janeiro, e principalmente, sua relação com o público de arte moderna, problematizando a relação entre a obra e o público. Nessa investigação, a forma artística é ressaltada como a mediadora entre arte e sociedade, possibilitando o aprofundamento das proposições clarkianas e seus desdobramentos no espaço dos museus modernos e a formação do público de arte através das fases de sua obra.

\section{Resultados e Discussão}

Através da análise da forma artística clarkiana e da trajetória da sua produção, buscou-se compreender as transformações internas à forma artística e sua relação com o contexto da arte moderna brasileira. Lygia Clark inicia seus estudos artísticos em 1947 no Rio de Janeiro, dando continuidade na França em 1950. Durante seus primeiros anos de estudo, Lygia trabalha especialmente em pinturas e desenhos. Em 1954 a artista desenvolve a Descoberta da Linha Orgânica, obra que dá início aos questionamentos sobre a forma e o espaço bidimensional. Após outros experimentos, na virada da década de 1950 para 1960, Lygia altera radicalmente seu espaço de construção artístico e técnica, elaborando os Bichos, série de chapas de metal moduláveis, inaugurando em sua trajetória a produção de obras voltadas para a participação e significação do público, corroborando na Teoria do Não Objeto. É então, a partir dos Bichos, que Lygia dá continuidade a uma série se novos experimentos na forma, passando em 1954 a elaborar obras relacionais, com as mais várias técnicas, propondo ao público que utilize tais objetos para criar relações entre si, encerrando sua trajetória nos anos 1970 com a série Estruturação do Self. Dessa maneira Lygia inaugura novos espaços e maneiras de relação entre a arte e o público, questionando também espaços como o museu de arte moderna, que antes voltados a exposições, se transformam à luz de novas experiências artísticas.

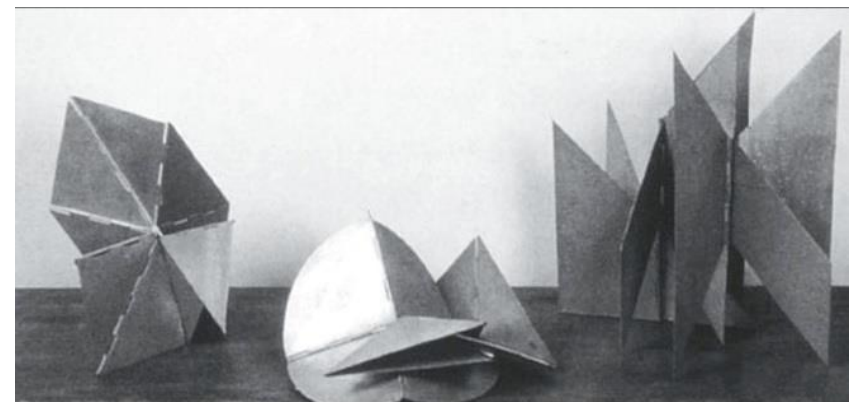

CLARK, Lygia. Bichos, 1964. Técnica: Chapas de Metal, Dimensões: Variadas.



CLARK, Lygia. Baba Antropofágica, 1973. Técnica: Linha de lã, Dimensões: Variadas.

\section{Conclusões}

Através da investigação da forma clarkiana, conclui-se que Lygia protagonizou diversas rupturas na maneira de propor aprofundamentos na relação entre a produção artística e a interação com o público. Do mesmo modo, Lygia também elabora questões de ruptura na relação com o Museu de Arte Moderna e os espaços que a arte ocupa no meio social, culminando em elementos de transição da arte moderna para a arte contemporânea no Brasil.

\section{Agradecimentos}

Agradeço ao PIBIC/CNPq, pelo apoio institucional e financeiro à pesquisa, à Profa. Dra. Mariana Miggiolaro Chaguri, pelos motivações e frutíferos diálogos ao longo da pesquisa, ao projeto Mundo Lygia Clark e ao setor de pesquisa do Museu de Arte Moderna do Rio de Janeiro. 